\title{
HIGH PREVALENCE OF DUODENAL ULCER IN A TERTIARY CARE HOSPITAL IN THE CITY OF SÃO PAULO, SP, BRAZIL
}

\author{
Sergio B. MARQUES, Rejane MATTAR, Everson L. A. ARTIFON, Paulo SAKAI and \\ Flair José CARRILHO
}

\begin{abstract}
Context - In spite of Helicobacter pylori infection being the etiological cause of peptic ulcer and its high prevalence in Brazil, the prevalence of peptic ulcer disease has been poorly studied. Objectives - To verify the peptic ulcer disease prevalence in patients of a tertiary care hospital. Methods - Diagnostic findings from 1,478 consecutive endoscopies were correlated with the urease test results for $\mathrm{H}$. pylori infection diagnosis and demographic data in a total of 3,779 endoscopies performed in 2005. The mean age of the patients was $51.14 \pm 16.46$, being $613(41.5 \%)$ men. Results - Peptic ulcer was diagnosed in $494(33.4 \%)$ patients with a mean age of $54.86 \pm 14.53,205(52 \%)$ were men, being $391(26.5 \%)$ duodenal ulcer and $103(7 \%)$ gastric ulcer. Normal endoscopy was found in $272(18.4 \%)$ patients with a mean age of $38.4 \pm 15.22$, being $49(18 \%)$ men. The comparison of peptic ulcer group with the patients that had normal endoscopy revealed that $H$. pylori infection $[P=0.005 ; \mathrm{OR}=1.70 ; 95 \% \mathrm{CI}=1.17-2.47]$, male gender $[P<0.0001$; $\mathrm{OR}=5.53 ; 95 \% \mathrm{CI}=3.67-8.34]$ and older age $[P<0.0001 ; \mathrm{OR}=1.08 ; 95 \% \mathrm{CI}=1.06-1.09]$ increased the risk of peptic ulcers. The overall $H$. pylori prevalence was $53 \%$ (786). Conclusions - Prevalence of duodenal ulcer is high in a Brazilian population that had $H$. pylori infection associated with older age and male gender as important determinants to gastrointestinal diseases outcome. Future prospective studies should confirm these findings.
\end{abstract}

HEADINGS - Peptic ulcer, epidemiology. Helicobacter infections.

\section{INTRODUCTION}

The evidence that $H$. pylori infection was the etiological cause of peptic ulcer disease and that the triple therapy with antibiotics would cure most of the $H$. pylori infections changed peptic ulcer disease conceptually and in practice, as an infectious disease ${ }^{(6)}$. Since then, the epidemiology of $H$. pylori infection has been studied among Brazilians, being dependent on age, socioeconomic status, and ethnicity, as well as sanitation conditions. High prevalence has been reported in the low income-community in Fortaleza (Northeastern Brazil), with $73.3 \%$ positive cases in individuals $11-20$ years old, and up to $87 \%$ in those over 60 years old ${ }^{(20)}$. In the city of São Paulo (Southern Brazil) that has high standard of living the prevalence of $H$. pylori was lower $(65.6 \%)^{(30)}$.

It was estimated that the lifetime risk for ulcer was higher in $H$. pylori-positive subjects, $10 \%-15 \%$ developed ulcer disease during long term follow-up in studies in developed areas of the world. It is unknown whether H. pylori-positive subjects in developing countries have similar disease risks ${ }^{(11)}$. Prevalence of peptic ulcer in Brazil has been poorly studied in spite of the high prevalence of $H$. pylori infection. A report from the South part of Brazil found low prevalence of duodenal ulcer $^{(24)}$, being more frequent in the male gender ${ }^{(15,24)}$, despite the preponderance of women in the peptic ulcer group in our studied population ${ }^{(14)}$.

As the peptic ulcer prevalence may be decreasing; the purpose of this study was to determine peptic ulcer prevalence in patients that had undergone upper gastrointestinal endoscopy in a tertiary care medical academic center.

\section{METHODS}

\section{Study population}

This study was approved by the local Ethics Committee. Diagnostic findings and demographic data were searched in the records of 1,478 consecutive gastrointestinal endoscopies in a total of 3,779 that were performed in 2005 for diagnostic purpose of dyspeptic patients at the Endoscopy Unit of the Hospital das Clínicas, a tertiary care academic medical center. The mean age of the patients was $51.14 \pm 16.46$, being $613(41.5 \%)$ men. Patients with peptic ulcer and those with normal endoscopy were grouped and their demographic data and $H$. pylori status were analyzed, and compared. Ulcer stage was classified according to Sakita ${ }^{(21)}$. Urease tests of $H$. pylori infection status were based on the results of antrum and corpus

Departamento de Gastroenterologia, Faculdade de Medicina da Universidade de São Paulo, SP, Brasi

Correspondence: Dr. Sergio B. Marques - Department of Gastroenterology - University of São Paulo School of Medicine - Av. Dr. Enéas de Carvalho Aguiar, 255 $9^{\circ}$ andar - sala 9159 - 05403-000 - São Paulo, SP, Brasil. E-mail:sergiobmarques@gmail.com 
biopsies placed into the homemade urease test according to a previously described technique ${ }^{(14)}$.

\section{Statistical analysis}

The correlation of age, gender, H. pylori status, and endoscopic findings were determined by the Student $t$-test, chi-square, and Fischer exact tests using SPSS software version 15.0 for Windows (Chicago, Illinois, USA). A $P$ value of less than 0.05 was considered statistically significant. Significant factors were subjected to multivariate stepwise logistic regression analysis, comparing peptic ulcer group with the one that had normal endoscopy.

\section{RESULTS}

In 1,478 endoscopies, peptic ulcer was found in 494 (33.4\%) patients and normal endoscopy in $272(18.4 \%)$ patients. Among the peptic ulcer group $391(26.5 \%)$ patients with a mean age of $54.86 \pm 14.53$, being $205(52 \%)$ men had duodenal ulcer. Gastric ulcer was diagnosed in $103(7 \%)$ patients with a mean age of $59.68 \pm 15.29$, being $56(54 \%)$ men. Patients with normal endoscopy had a mean age of $38.4 \pm 15.22$, being $49(18 \%)$ men (Table 1).

TABLE 1 . Demographic data and $H$. pylori status in 494 patients with peptic ulcer and 272 with normal endoscopy in a total of 1,478 consecutive endoscopies performed

\begin{tabular}{lcccc}
\hline $\begin{array}{l}\text { Endoscopic } \\
\text { finding }\end{array}$ & $\begin{array}{c}\text { Mean } \\
\text { age }\end{array}$ & $\begin{array}{c}\text { Male } \\
\text { gender }\end{array}$ & $\begin{array}{c}\text { H. pylori } \\
\text { positive }\end{array}$ & Total (\%) \\
\hline Normal & $38.4 \pm 15.22$ & $49(18 \%)$ & $143(53 \%)$ & $272(18.4)$ \\
Duodenal ulcer & $54.86 \pm 14.53$ & $205(52 \%)$ & $252(64 \%)$ & $391(26.5)$ \\
Gastric ulcer & $59.68 \pm 15.29$ & $56(54 \%)$ & $59(57 \%)$ & $103(7 \%)$ \\
\hline
\end{tabular}

There was a significant difference between the mean age of patients with normal endoscopy and the peptic ulcer group $(38.4 \pm 15.22 ; 55.87 \pm 14.80 ; P<0.001)$ and the mean age of patients with gastric ulcer and the patients with duodenal ulcer $(59.68 \pm 15.29 ; 54.83 \pm 14.79 ; P=0.004)$.

The overall prevalence of $H$. pylori infection was $53 \%$ (786) out of a total of 1,478 individuals. H. pylori infection was positive in $252(64 \%, P<0.05)$ of the patients with duodenal ulcer, $59(57 \%)$ of the patients with gastric ulcer and in $143(53 \%)$ of those with normal endoscopy (Table 1). The comparison of peptic ulcer group with the patients that had normal endoscopy revealed that $H$. pylori infection $[P=0.005 ; \mathrm{OR}=1.70 ; 95 \% \mathrm{CI}=1.17-2.47]$, male gender $[P<0.0001 ; \mathrm{OR}=5.53 ; 95 \% \mathrm{CI}=3.67-8.34]$ and older age $[\mathrm{P}<0.0001 ; \mathrm{OR}=1.08 ; 95 \% \mathrm{CI}=1.06-1.09]$ increased the risk of peptic ulcers.

Most of the gastric $(81 ; 54 \%)$ and duodenal ulcers $(296 ; 54 \%)$ were in the scar stage (S) (Table 2). Within the duodenal ulcer group, 15 patients with serious comorbidities had $H$. pylorinegative active (A) ulcer. H. pylori was negative in $9(20 \%)$ of those in healing $(\mathrm{H})$ and $115(39 \%)$ in scar stages $(\mathrm{S})$.

The analysis of endoscopic findings associated with gastric and duodenal ulcers (Table 3), showed that antral erosive gastritis was the most frequent endoscopic finding and the rate of antral gastritis in both groups of ulcers was similar. Esophagitis was more frequently observed in the duodenal ulcer group, and, unexpectedly atrophic gastritis.

TABLE 2. Stage of the peptic ulcer groups according to the Sakita classification

\begin{tabular}{lcc}
\hline Sakita & Gastric ulcer (\%) & Duodenal ulcer (\%) \\
\hline A & $35(23)$ & $49(13)$ \\
$\mathrm{H}$ & $35(23)$ & $46(12)$ \\
$\mathrm{S}$ & $81(54)$ & $296(54)$ \\
Total & 151 & 391 \\
\hline \multicolumn{2}{l}{ The stage of gastric and duodenal ulcers is included in gastric ulcer group and in the duodenal } \\
ulcer group
\end{tabular}

TABLE 3. Endoscopic findings associated with gastric and duodenal ulcers

\begin{tabular}{lcc}
\hline Endoscopic findings & Gastric ulcer $\mathbf{n}(\%)$ & Duodenal ulcer $\mathbf{n}(\%)$ \\
\hline Gastritis & $52(50.5)$ & $217(55.5)$ \\
Antral gastritis & $45(43.7)$ & $173(44.2)$ \\
Superficial & $11(10.7)$ & $51(13.0)$ \\
Erosive & $34(33)$ & $122(31.2)$ \\
Corpus gastritis & $0(0)$ & $7(1.8)$ \\
Superficial & $0(0)$ & $5(1.3)$ \\
Erosive & $0(0)$ & $2(0.5)$ \\
Pangastritis & $6(5.8)$ & $34(8.7)$ \\
Superficial & $3(2.9)$ & $20(5.1)$ \\
Erosive & $3(2.9)$ & $14(3.6)$ \\
Atrophic gastritis & $1(1)$ & $11(2.8)$ \\
Esophagitis & $9(8.7)$ & $67(17.1)$ \\
Duodenitis & $22(21.4)$ & $60(15.3)$ \\
Superficial & $2(1.9)$ & $10(2.6)$ \\
Erosive & $20(19.4)$ & $50(12.8)$ \\
\hline
\end{tabular}

\section{DISCUSSION}

Gastric colonization with $H$. pylori induces chronic gastritis that may be asymptomatic through all lifelong, being intriguing that only $10 \%$ to $20 \%$ of infected individuals have lifetime risk of developing ulcer disease ${ }^{(11)}$. However, infection with more pathogenic $H$. pylori isolates with positive cagPAI genes ${ }^{(15}$, ${ }^{17)}$ was previously shown as risk of ulcer disease outcome. Other factors were being between 40 and 60 years of age, being male, cigarette smoking, alcohol consumption, use of aspirin or NSAIDs, heavy social psychological stress, frequent mobility, irregular working hours, low socioeconomic status, higher acid output, and heredity ${ }^{(4,5,29)}$.

The worldwide ulcer prevalence differs, with duodenal ulcers dominating in Western populations and gastric ulcers being more frequent in Asia, especially in $\mathrm{Japan}^{(29)}$. In the present study $33.4 \%$ of the patients had peptic ulcer disease, mainly, duodenal ulcer $(26.5 \%)$ that was high in comparison to Southern Brazil $(3.3 \%)^{(24)}$, Philippines $(10.3 \%)^{(27)}$ and Turkey $(16.8 \%)^{(23)}$. Even though the overall prevalence of $H$. pylori infection was lower than previous reported $(65 \%)$ in the city of São Paulo ${ }^{(30)}$, in Southern Brazil $(63.4 \%)^{(22)}$, and 
in Northeastern Brazil (92\% in subjects $46-60$ years) ${ }^{(19,20)}$; the prevalence of peptic ulcers has not changed in countries with a low prevalence of $H$. pylori infection due to eradication regimens ${ }^{(13)}$.

The risk of infected individuals to develop peptic ulcer was found to be 1.7 [95\% CI $=1.17-2.47]$ which is similar to other reports that showed a relative risk of 1.6-5.7 (mean, 3.3) for infected people of developing peptic ulcer, compared with non-infected people ${ }^{(5)}$. Male gender $[\mathrm{OR}=5.53 ; 95 \% \mathrm{CI}$ $=3.67-8.34$ ] and aging, as previously reported ${ }^{(26,28)}$, were also risks of peptic ulcer development. Within the peptic ulcer group, gastric ulcer group had significantly higher age; the incidence of gastric ulcer has been relatively higher in the elderly people, compared to that of duodenal ulcers ${ }^{(26)}$ that may be due to lower defensive factors such as poor gastrin-elevating action capable of healing by its trophic effect ${ }^{(8)}$, decreased mucus, bicarbonate secretion and prostaglandins ${ }^{(12)}$.

Endoscopic erosive antral gastritis was more frequent than corpus gastritis in both gastric and duodenal ulcer groups, in our previous report the activity of inflammation was also more intense in the antrum of peptic ulcer patients ${ }^{(14)}$; in addition, gastritis was more intense in the peptic ulcer group than in those with normal endoscopy and $H$. pylori positive $^{(15)}$. Endoscopic diagnosis has been $62 \%$ as sensitive as histological diagnosis for erosive gastritis and $84 \%$ for atrophic gastritis in the antrum ${ }^{(10)}$. In India, the antral gastritis also predominated in $82 \%$ of the cases, and $H$. pylori was usually found in gastric biopsies taken from the antrum ${ }^{(16)}$.

Association of duodenal ulcer with esophagitis was already described at higher rates of $33 \% \%^{(1)}$ than in the present study $(17 \%)$. One possible explanation is higher acid secretion that has a role in the etiology of duodenal ulcer ${ }^{(9)}$ and gastroesophageal reflux disease and its complications ${ }^{(7)}$ more frequently found in the male gender ${ }^{(3)}$. The unexpected cases of duodenal ulcer with atrophic gastritis may be the result of a long-term use of proton pump inhibitors ${ }^{(18)}$.

Most of the gastric (54\%) and duodenal ulcers (54\%) were in the $\mathrm{S}$ stage which may explain the prevalence of $H$. pylori infection of $57 \%$ and $64 \%$, respectively; which may indicate that were eradication-control patients. Within the duodenal ulcer group, 15 patients with serious co-morbidities had $H$. pylori-negative A ulcer. The clinical characteristics described of patients with $H$. pylori-negative duodenal ulcers were more likely to be older, have concomitant medical problem, pre-existing malignancy, recent surgery, underlying sepsis, or taken non-steroidal anti-inflammatory drugs ${ }^{(2)}$.

This study has some limitations as the information concerning proton pump inhibitors, aspirin or NSAIDs intake, cigarette smoking, and alcohol consumption was not available. In addition, $H$. pylori infection was based in a single test (urease) and may be underestimated by the use of proton pump inhibitors, even though biopsies were taken from the antrum and the corpus, presenting 97.4\% sensitivity and $100 \%$ specificity ${ }^{(25)}$. A prospective study should further clarify these factors.

\section{CONCLUSION}

We conclude that the prevalence of duodenal ulcer is high in a Brazilian population that had $H$. pylori infection associated with older age and male gender as important determinants to gastrointestinal diseases outcome.

\section{ACKNOWLEDGMENTS}

This study was partially supported by CAPES (Coordenação de Aperfeiçoamento de Pessoal de Nível Superior) and Alves Queiroz Family Fund for Research.

Marques SB, Mattar R, Artifon ELA, Sakai P, Carrilho FJ. Alta prevalência de úlcera duodenal num hospital terciário na cidade de São Paulo. Arq Gastroenterol. 2011;48(3):171-4.

RESUMO - Contexto - Apesar da infecção pelo Helicobacter pylori ser causa de úlcera péptica e de sua alta prevalência no Brasil, a prevalência da úlcera péptica tem sido pouco estudada. Objetivos - Verificar a prevalência da doença ulcerosa péptica em pacientes de um hospital terciário. Métodos Achados diagnósticos de 1.478 endoscopias consecutivas foram correlacionados com os resultados de testes de urease para diagnóstico de infecção pelo $H$. pylori e dados demográficos num total de 3.779 endoscopias realizadas em 2005 . A média de idade dos pacientes foi $51,14 \pm 16,46$, sendo $613(41,5 \%)$ homens. Resultados - A úlcera péptica foi diagnosticada em $494(33,4 \%)$ pacientes com média de idade de 54,86 $\pm 14,53,205(52 \%)$ eram homens, sendo 391 (26,5\%) úlceras duodenais e 103 (7\%) úlceras gástricas. Endoscopia normal foi achada em $272(18,4 \%)$ pacientes com média de idade de 38,4 $\pm 15,22$, sendo $49(18 \%)$ homens. A comparação do grupo de úlcera péptica com os pacientes que tinham endoscopia normal revelou que a infecção pelo H. pylori $[P=0,005 ; \mathrm{OR}=1,70 ; 95 \% \mathrm{CI}=1,17-2,47]$, gênero masculino $[P<0,0001 ; \mathrm{OR}=5,53 ; 95 \% \mathrm{CI}=3,67-8,34]$ e idade mais avançada $[P<0,0001 ; \mathrm{OR}=1,08 ; 95 \% \mathrm{CI}=1,06-1,09]$ aumentaram o risco de úlceras pépticas. A prevalência de infecção pelo $H$. pylori no total foi de 53\% (786). Conclusões - A prevalência da úlcera duodenal é alta numa população brasileira de um hospital terciário que teve a infecção pelo $H$. pylori, idade avançada e gênero masculino como determinantes importantes de evolução para doença gastrointestinal. Estudos futuros prospectivos devem confirmar esses achados.

DESCRITORES - Úlcera péptica, epidemiologia. Infecções por helicobacter. 


\section{REFERENCES}

1. Boyd EJ. The prevalence of esophagitis in patients with duodenal ulcer or ulcerlike dyspepsia. Am J Gastroenterol. 1996;91:1539-43.

2. Chu KM, Kwok K-F, Law S, Wong KH. Patients with Helicobacter pylori positive and negative duodenal ulcers have distinct clinical characteristics. World J Gastroenterol. 2005;11:3518-22.

3. Derakhshan MH, El-Omar E, Oien K, Gillen D, Fyfe V, Crabtree JE, McColl KE. Gastric histology, serological markers and age as predictors of gastric acid secretion in patients infected with Helicobacter pylori. J Clin Pathol. 2006;59:1293-9.

4. Dong WG, Cheng CS, Liu SP, Yu JP. Epidemiology of peptic ulcer disease in Wuhan area of China from 1997 to 2002. World J Gastroenterol. 2004,10:3377-9.

5. Duggan JN, Duggan AE. The possible causes of the pandemic of peptic ulcer in the late $19^{\text {th }}$ and early $20^{\text {th }}$ century. Med J Aust. 2006;185:667-9.

6. Graham D. Foreword. In: Lee A, Mégraud F, editors. Helicobacter pylori: techniques for clinical diagnosis \& basic research. London: Saunders; 1996.

7. Hirschowitz BI, Simmons JL, Johnson LF, Mohnen J. Risk factors for esophagitis in extreme acid hypersecretors with and without Zollinger-Ellison syndrome. Clin Gastroenterol Hepatol. 2004;2:220-9.

8. Ishihara M, Ito M. Influence of aging on gastric ulcer healing activities of cimetidine and omeprazole. Eur J Pharmacol. 2002;444:209-15.

9. Jacobson K, Chiba N, Chen Y, Barrientos M, James C, Riddell RH, Hunt RH. Gastric acid secretory response in Helicobacter pylori-positive patients with duodenal ulcer disease. Can J Gastroenterol. 2001;15:29-39.

10. Kaminishi M, Yamaguchi H, Nomura S, Oohara T, Sakai S, Fukutomi H, Nakahara A, Kashimura H, Oda M, Kitahora T, Ichikawa H, Yabana T, Yagawa Y, Sugiyama T, Itabashi M, Unakami M, Oguro Y, Sakita T. Endoscopic classification of chronic gastritis based on a pilot study by the research society for gastritis. Dig Endosc. 2002;14:138-51.

11. Kusters JG, van Vliet AHM, Kuipers EJ. Pathogenesis of Helicobacter pylori Infection. Clin Microbiol Rev. 2006;49:449-90.

12. Laine L, Tokeuchi K, Tarnawski A. Gastric mucosal defense and cytoprotection: bench to bedside. Gastroenterology. 2008;135:41-60.

13. Manuel D, Cutler A, Goldstein J, Fennerthy MB, Brown K. Decreasing prevalence combined with increasing eradication of Helicobacter pylori infection in the United States has not resulted in fewer hospital admissions for peptic ulcer disease-related complications. Aliment Pharmacol Ther. 2007;25:1423-7.

14. Mattar R, dos Santos AF, Eisig JN, Rodrigues TN, Silva FM, Lupinacci RM, Iriya K, Carrilho FJ. No correlation of babA2 with vacA and $\operatorname{cag} \mathrm{A}$ genotypes of Helicobacter pylori and grading of gastritis from peptic ulcer disease patients in Brazil. Helicobacter. 2005;10:601-8.

15. Mattar R, Marques SB, Monteiro Mdo S, Dos Santos AF, Iriya K, Carrilho FJ. Helicobacter pylori cag pathogenicity island genes: clinical relevance for peptic ulcer disease development in Brazil. J Med Microbiol. 2007;56:9-14.

16. Misra V, Misra S, Dwivedi M, Singh UP, Bhargava V, Gupta SC. A topographic study of Helicobacter pylori density, distribution and associated gastritis. J Gastroenterol Hepatol. 2000;15:737-43.
17. Pacheco AR, Proença-Módena JL, Sales AI, Fukuhara Y, da Silveira WD, Pimenta-Módena JL, de Oliveira RB, Brocchi M. Involvement of the Helicobacter pylori plasticity region and cag pathogenicity island genes in the development of gastroduodenal diseases. Eur J Clin Microbiol Infect Dis. 2008;27: 1053-9.

18. Raghunath AS, O'Morain C, McLoughlin RC. Review article: the long-term use of proton-pump inhibitors. Aliment Pharmacol Ther. 2005;22:55-63.

19. Rodrigues MN, Queiroz DM, Rodrigues RT, Rocha AM, Braga Neto MB, Braga LL. Helicobacter pylori infection in adults from a poor urban community in northeastern Brazil: demographic, lifestyle and environmental factors. Braz J Infect Dis. 2005;9:405-10.

20. Rodrigues MN, Queiroz DM, Rodrigues RT, Rocha AM, Luz CR, Braga LL. Prevalence of Helicobacter pylori infection in Fortaleza, Northeastern Brazil Rev Saúde Publica. 2005;39:847-9.

21. Sakita T. Endoscopy in diagnosis of early gastric cancer. Clin Gastroenterol. $1973 ; 2: 345-60$

22. Santos IS, Boccio J, Santos AS, Valle NC, Halal CS, Bachilli MC, Lopes RD Prevalence of Helicobacter pylori infection and associated factors among adults in Southern Brazil: a population-based cross-sectional study. BMC Public Health. 2005;5:118.

23. Sari YS, Sander E, Erkan E, Tunalı V. Endoscopic diagnoses and CLO test results in 9239 cases, prevalence of Helicobacter pylori in Istanbul, Turkey. J Gastroenterol Hepatol. 2007;22:1706-11.

24. Saul C, Teixeira CR, Pereira-Lima JC, Ronaldo J, Torresini RJ. Redução da prevalência de úlcera duodenal: um estudo brasileiro (análise retrospectiva na última década: 1996-2005). Arq Gastroenterol. 2007;44:320-4.

25. Vaira D, Vakil N, Gatta L, Ricci C, Perna F, Saracino I, Fiorini G, Holton J Accuracy of a new ultrafast rapid urease test to diagnose Helicobacter pylor infection in 1000 consecutive dyspeptic patients. Aliment Pharmacol Ther. 2010;31:331-8

26. Watanabe Y,Kurata JH, Kawamoto K, Kawai K. Epidemiological study of peptic ulcer disease among Japanese and Koreans in Japan. J Clin Gastroenterol. 1992;15:68-74.

27. Wong S N, Sollano JD, Chan MM, Carpio RE, Tady CS, Ismael AE, Judan-Ruiz EA, Ang VN, Go JT, Lim VY, Perez JY, Alvarez SZ. Changing trends in peptic ulcer prevalence in a tertiary care setting in the Philippines: A seven-year study. J Gastroenterol Hepatol. 2005;20:628-32.

28. Wu HC, Tuo BG, Wu WM, Gao Y, Xu QQ, Zhao K. Prevalence of peptic ulcer in dyspeptic patients and the influence of age, sex, and Helicobacter pylori infection. Dig Dis Sci. 2008;53:2650-6.

29. Yuan Y, Padol IT, Hunt RH. Peptic ulcer disease today. Nat Clin Pract Gastroenterol Hepatol. 2006;3:80-9.

30. Zaterka S, Eisig JN, Chinzon D, Rothstein W. Factors related to Helicobacter pylori prevalence in an adult population in Brazil. Helicobacter. 2007;12:82-8.

Received 22/6/2010 Accepted 23/7/2010 